\title{
INFLUENCE OF HIGH TEMPERATURE ON DAIRY PRODUCTIVITY OF UKRAINIAN SCHWYZ
}

\author{
Vasilenko Tetyana ${ }^{1}$ \\ Milostiviy Roman ${ }^{2}$ \\ Kalinichenko Olena ${ }^{3}$
}

DOI: http://dx.doi.org/10.30525/978-9934-571-26-8_3

Abstract. In monitoring studies of recent years, global warming is reported. This is a significant problem for dairy farming in much of Europe, especially in the central and southern regions, as reported by numerous studies. Dairy cattle highly productive are extremely sensitive to hot temperatures; their consequence is health problems, a significant reduction in milk yield and milk quality. Unfortunately, heat stress remains an unrecognized problem for domestic cattle breeding, although the financial losses from its harmful influence in European are quite substantial. The aim of our work was to study the effect of high temperatures on milk yield of cows of Ukrainian Schwitz on one of the complexes of high-tech milk production. At the beginning of the research, we decided to test the hypothesis of increasing hot air temperatures in the warm period of the year compared with the long-term data. Then we studied how the milk of Schwitz breed varies during the hot season, depending on the magnitude of the maximum temperature values. According to the results of the study, it can be noted that the air temperature during the warm period of 2017 tended to increase $\left(+0.6^{\circ} \mathrm{C}\right)$ in comparison with the long-term data. In August, the air temperature significantly exceeded the long-term data by $+3{ }^{\circ} \mathrm{C}(\mathrm{td}=2.89, \mathrm{P}<0.05)$. The obtained results testify that in the conditions of the central region of Ukraine in the warm period of the year the probability of occurrence of heat stress in dairy cows is high. In the warm season of 2017, the period during which THI exceeded the comfortable value for dairy cows was 100 days. At the same time, a decrease in productivity per cow in the hot season may

\footnotetext{
${ }^{1}$ Candidate of Agricultural Sciences, Associate Professor,

Dnepropetrovsk State Agrarian-Economic University, Ukraine

${ }^{2}$ Candidate of Veterinary Sciences, Associate Professor,

Dnepropetrovsk State Agrarian-Economic University, Ukraine

${ }^{3}$ Candidate of Agricultural Sciences, Associate Professor,

Dnepropetrovsk State Agrarian-Economic University, Ukraine
} 
amount to $146 \mathrm{~kg}$ of milk, and the loss may reach 39.5 EUR / cow. To prevent heat stress in conditions of year-round maintenance of dairy cattle, it is advisable to use active ventilation systems with humidification of air. The relationship between the temperature and milk yield of cows is revealed by an average degree of reliability $(\mathrm{r}=-0.45, \mathrm{P}<0.05)$. Compared with the most favorable external conditions in May, the cows' milk yield decreased in June by $3.0 \%$, the yield of milk fat by $5.2 \%$, the milk protein content by $3.4 \%(\mathrm{P}<0.001)$. In July and August, the cows' milk yield decreased by 4.6 and $5.5 \%(\mathrm{P}<0.001)$, the yield of milk fat decreased by 3.1 and $7.3 \%$ $(\mathrm{P}<0.01-0.001)$, the yield of milk protein 3.4 and $5.7 \%(\mathrm{P}<0.001)$. Thus, high temperatures during the summer period contributed to a decrease in milk yield and the main components of milk of the Ukrainian Schwitz, which can lead to tangible financial losses.

\section{Introduction}

In monitoring studies of recent years, global warming is reported. This is a significant problem for dairy farming in much of Europe, especially in the central and southern regions, as reported by numerous studies. According to experts [17, p. 18], for the EU countries the problem of heat stress is quite relevant. In the summer, losses in the dairy sector can be about $3 \mathrm{~kg}$ of milk per cow per day. In the southern regions of Europe (Spain, Italy and southern France) cattle are exposed to heat stress for most of the day (13-18 hours), losing up to $5.5 \mathrm{~kg}$ of milk per cow per day. And even in the northern regions of Europe (Switzerland, Czech Republic and Poland), dairy cows can be exposed to heat stress from 6 to 10 hours a day. A sharp increase in the temperature of the environment in Eastern Europe leads to an increase in cases of abnormal heat during the summer time (the duration of the stress period may be 30 to 60 days), which leads to a deterioration in the conditions of animals and financial losses in dairy cattle. Dairy cattle highly productive are extremely sensitive to hot temperatures; their consequence is health problems $[7, \mathrm{p} .260$; 9, p. 37], a significant reduction in milk yield and milk quality [12, p. 1]. Unfortunately, heat stress remains an unrecognized problem for domestic cattle breeding, although the financial losses from its harmful influence in European countries are estimated at an average of more than 400 euro per cow per year [17, p. 18]. Previous studies [14, p. 229] indicate a high probability of occurrence of thermal stress in cows in the conditions of 
high temperatures in the central part of Ukraine and significant economic losses in dairy cattle breeding [20, p. 128].

The aim of this work was to study the influence of high temperatures in summer on the productivity of cow's of the Schwitz, in conditions of keeping in stalls all year round with a paddocks in the large dairy complex.

\section{Materials and Methods}

Long-term data, as well as the dynamics of air temperatures in the warm period of 2017 (from May to September inclusive) at the location of the dairy complex (where the animals are kept in light barns) were taken into account by analyzing the materials of the weather report archive (www. accuweather.com). The yield of cows was assessed using the herd management system "Dairy Comp 305«. The average amount of milk received per day, the yield of milk fat and protein per herd of cows was taken into account throughout the study period. To process the data obtained and to evaluate the reliability of the indicators, the software Statistica 10 was used. In order to assess the likelihood of occurrence of heat stress, during the warm period of 2017, every day at different times of the day (four times), the air temperature and relative humidity were measured. The temperature-humidity index was determined by the conventional method (Kibler, 1964):

$$
T H I=1.8 \times T-(1-R H / 100) \times(T-14.3)+32 \text {, where }
$$

THI is the temperature-humidity index

$T$ is the ambient temperature $\left({ }^{\circ} \mathrm{C}\right)$;

$R H$ is the relative humidity of air (\%).

\section{Influence of high temperature on dairy productivity}

It was found that the average temperature during the warm period of the year from May to September $2017\left(26.4^{\circ} \mathrm{C}\right)$, slightly increased $\left(0.6^{\circ} \mathrm{C}\right)$, compared with the long-term data, but did not have significant differences $(\mathrm{td}=1.07 ; \mathrm{P}>0.05)$. However, in August this year was hotter than the longterm data. The air temperature exceeded the average values by $3.0^{\circ} \mathrm{C}$ $(\mathrm{td}=2.89, \mathrm{P}<0.001)$, and in certain periods of this month the excess of the multi-year maximum was $8.0^{\circ} \mathrm{C}$. Unusually hot was September, the difference between long-term data and temperature in certain periods this month was $10-13{ }^{\circ} \mathrm{C}$, at the highest temperatures up to $35^{\circ} \mathrm{C}$, which is not very typical for this time of year (Figure 1). 


\section{Influence of high temperature on dairy productivity of Ukrainian schwyz...}

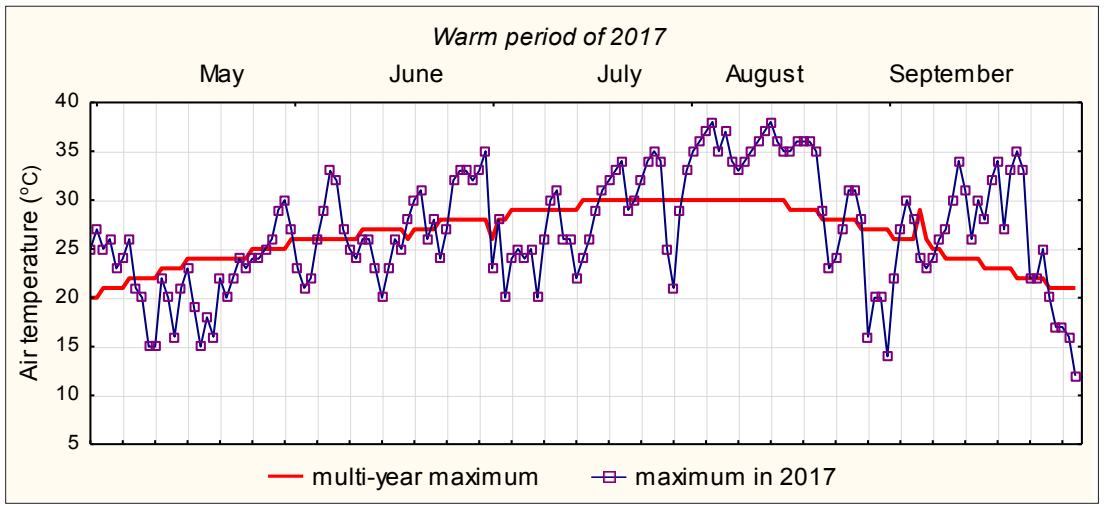

Fig. 1. Dynamics of maximum temperatures during the period from May to September

Analysis of the state of the air environment and the level of productivity of animals in the hot period indicates a significant dependence of the daily milk yield on the temperature of the air, between which the average degree of negative correlation $(\mathrm{r}=-0.45 ; \mathrm{P}<0.05)$ was detected. As can be seen from the data (Figure 2), periods of growth of external temperatures were accompanied by a significant decrease in the daily milk yield in cows.

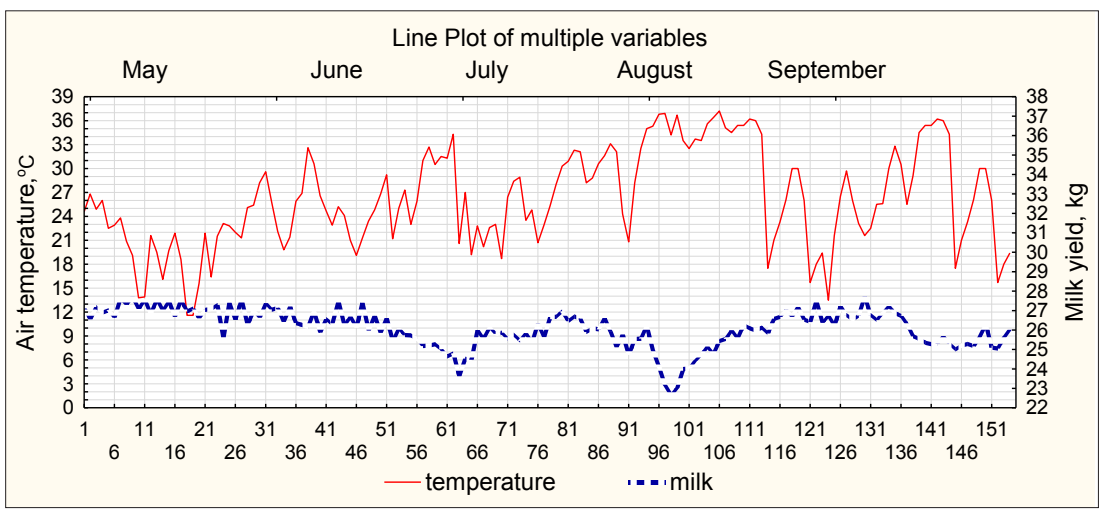

Fig. 2. Dependence of daily milk yield on external temperatures during the hot season 
We found that the most favorable temperature conditions for the manifestation of milk productivity in cows were in May. This month, with an average air temperature of $14.7^{\circ} \mathrm{C}$, the average yield of milk in a herd of cows averaged $27.1 \mathrm{~kg}$ per day. We compared how high temperatures in the summer affected this figure in the future. In June, the average air temperature increased by $5^{\circ} \mathrm{C}$ and amounted to $19.7^{\circ} \mathrm{C}$. This resulted in a decrease in milk yield of cows by $3.0 \%(\mathrm{P}<0.001)$. The yield of milk fat decreased by $5.2 \%(\mathrm{P}<0.001)$. The rise in temperature was also reflected in the yield of milk protein, the amount of which decreased by $3.4 \%(\mathrm{P}<0.001)$. Thus, the content of these indicators in June decreased by $850 ; 50$ and $30 \mathrm{~g}$ respectively (Figure 3).

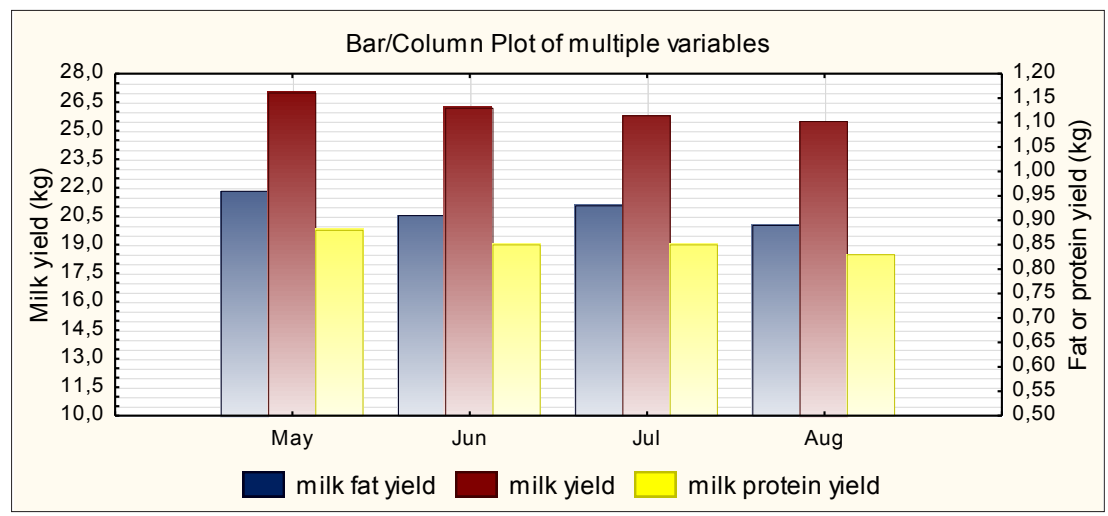

Fig. 3. Dynamics of milk production productivity in the heat of the year 2017

In July, the average air temperature was $20.7^{\circ} \mathrm{C}$, that is, it increased by $6.0^{\circ} \mathrm{C}$ compared to May. This led to a decrease in milk yield by $4.6 \%$ $(\mathrm{P}<0.001)$, milk fat yield by $3.1(\mathrm{P}<0.01)$ and milk protein yield by 3.4 ( $\mathrm{P}$ $<0.001$ ), or by $1390 ; 30$ and $30 \mathrm{~g}$ respectively.

August was the hottest month of summer. The average temperature was at $23.4^{\circ} \mathrm{C}$. Its increase of $9.2^{\circ} \mathrm{C}$ compared to May, led to a decrease in milk yield of cows by $5.5 \%(\mathrm{P}<0.001)$, milk fat yield by $7.3 \%(\mathrm{P}<0.001)$ and protein yield by $5.7 \%(\mathrm{P}<0.001)$ or $1540 ; 70$ and $50 \mathrm{~g}$ respectively. It should be noted that the monthly fluctuations in fat and protein content in milk (\%) were not reliable. 


\section{Heat stress in dairy cows and its economic consequences}

Hot temperatures and, in particular, heat stress, affect the health of animals through direct or indirect effects on physiology, metabolism, hormonal and immune system $[8$, p. $86 ; 18$, p. $96 ; 13$, p. 366]. The decline in productivity in dairy cows is associated, first of all, with a decrease in food intake and changes in the digestive tract [1, p. 311; 4, p. 4939].

The materials obtained about the decrease in the yield of milk and its components in cows under the influence of high temperatures are consonant with the results of other researchers. It is reported [3, p. 479] on the reduction of dry matter intake of feed (by $9.6 \%$ ) and decrease in milk yield (by $21 \%$ ) with a rise in temperature-humidity index (THI) from 68 to 78 . The increase in THI per unit over 69 was the reason reduction of milk yield in cows by $0.41 \mathrm{~kg}$ [19, p. 759]. It is enough four hours of finding cows in conditions of moderate heat stress for the loss of $1 \mathrm{~kg}$ of milk per day $[5$, p. 5]. High temperature and humidity not only caused the decrease in milk yield in cows, but also helped to reduce the yield of fat and milk protein by 39.7 and $16.9 \%$ [11, p. 59].

At high air temperatures, the temperature-humidity index (THI) is a common indicator of the assessment of heat stress (Kibler, 1964). To ensure comfortable conditions for animals, the THI value should be below 68 . THI at 68-71 corresponds to low stress, $72-79$ to moderate stress, 80 to 89 to severe stress and 90 to 99 to very high stress [17, p. 18].

We have studied the possibility of occurrence of heat stress in animals during the hot season of 2017 (from May to September). It is established (Table 1) that the value of the THI indicator directly depended on the temperature regime of the ambient air $(\mathrm{r}=0.98, \mathrm{P}>0.95)$.

Table 1

Average parameters of the temperature-humidity regime of the environment in the warm period of 2017

\begin{tabular}{lcccccc}
\hline \multicolumn{1}{c}{ Month } & \multicolumn{2}{c}{ Temperature of air, ${ }^{\circ} \mathbf{C}$} & \multicolumn{2}{c}{ Humidity of air, $\%$} & \multicolumn{2}{c}{ THI } \\
\hline & $\mathrm{M}$ & $\mathrm{m}$ & $\mathrm{M}$ & $\mathrm{m}$ & $\mathrm{M}$ & $\mathrm{m}$ \\
\hline May & 14.7 & 0.51 & 62.0 & 1.83 & 57.5 & 0.68 \\
\hline June & 19.7 & 0.47 & 60.9 & 1.65 & 64.9 & 0.58 \\
\hline July & 20.7 & 0.49 & 66.2 & 1.70 & 66.3 & 0.59 \\
\hline August & 23.4 & 0.60 & 53.0 & 1.90 & 68.8 & 0.65 \\
\hline September & 19.9 & 0.54 & 59.6 & 2.01 & 64.4 & 0.60 \\
\hline
\end{tabular}


As can be seen from the data presented, the average THI in August corresponded to the level of low stress. However, during the hot period of the day, throughout the warm period of the year taken for evaluation (May-September), the animals could be in a state of thermal stress of one or another force. So, in May, the value of THI in which dairy cattle could be in a state of heat stress was 5 days, including 3 days corresponding to a small stress and 2 days to moderate stress.

In June the value of THI in which dairy cattle could be in a state of heat stress was 25 days, of which 12 days corresponded to a low stress and 12 days to a moderate stress.

In July the value of THI during the period of maximum temperature rise, during the day at which dairy cattle could be in a state of heat stress was 22 days. However, the degree of manifestation of a possible stress reaction increased. During this period, the animals could be in a state of thermal stress of strong action (THI> 80) one day; 18 days corresponded to mild stress and only 3 days - a state of low stress.

The hottest was August 2017 (Figure 4). The number of days when dairy cattle could experience the heat stress of a strong effect was 7 days, moderate -17 and only 2 days a little stress. In this case, the THI value exceeding the comfort zone of the animals (68) this month was observed for 26 days.

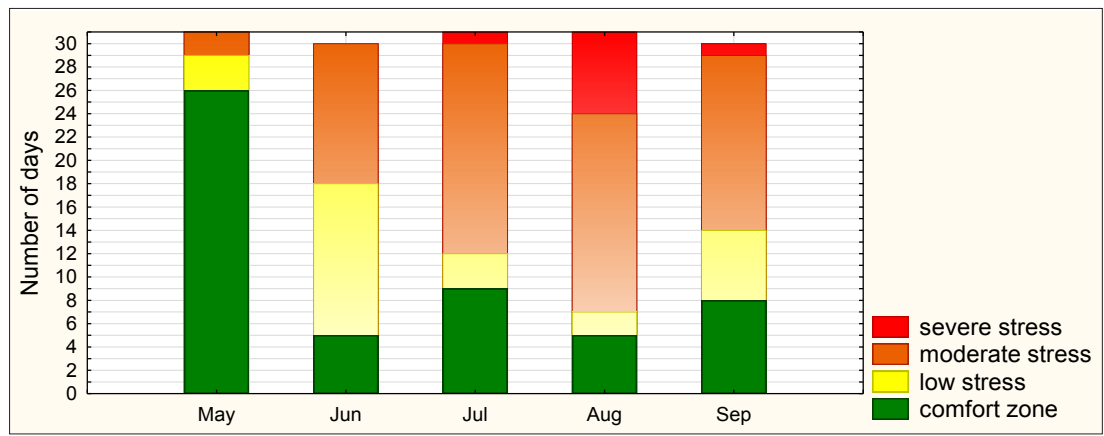

Fig. 4. Probability of heat stress in dairy cattle

Despite the long-term trend of temperature decrease, September, the year 2017 was characterized by significant maximum daily temperatures, the highest of which was raised to $+33 \ldots+35^{\circ} \mathrm{C}$ and higher. 
At the same time, the THI value, in which animals could be exposed to severe heat stress, was recorded for 1 day, moderate stress of 15 days and a slight stress of 6 days. In general, the number of days exceeding the conditions of comfort for animals in September was 22 days.

Thus, the index THI, which exceeded the value of comfort for dairy cows in the warm period in 2017 (from May to September inclusive), recorded over 100 days. This amounted to approximately $35 \%$ of the warm period of the year. Of these, 73 days were recorded during the hot summer period.

To prevent the effects of high temperatures in the barns of the dairy complex, active ventilation is used using the longitudinal arrangement of the fans. However, their independent use (without air humidification) proved to be insufficiently effective. As a consequence, for the period from June to September 2017 inclusive, losses per cow amounted to $146 \mathrm{~kg}$ of milk. Given the average price of milk sales in Ukraine (in terms of euro at the rate of the National Bank), as a result of high temperatures in the hot season of 2017 , the company incurred a loss in the dairy herd at a rate of 37.5 thousand $€$, or $39.5 €$ per 1 cow.

\section{Technical solutions for preventing heat stress}

Modification of the air environment of premises in hot weather usually consists of keeping dairy cows under shady canopies with ventilation-turbine blowing and spraying. In the results published in 1988 [23, p. 809], it was shown that the combination of wetting and forced ventilation can reduce the daily increase in rectal temperature by $0.3^{\circ} \mathrm{C}$ and increase the milk yield of cows by $3.6 \mathrm{~kg}$ per day. It is reported [22, p. 74] that the contents of cows in stalls throughout the year, the parameters of the air environment in the "cold" barn of the frame type were approximated as much as possible to the conditions of the environment. An increase in the external temperature from 19.6 to $33.0^{\circ} \mathrm{C}$, led to an increase in the indoors temperature from 20.4 to $28.5^{\circ} \mathrm{C}$. At the same time [15, p. 291] the use of the active ventilation and spraying system in the barn during the heat, prevented the rectal temperature increase in the cows by $0.4^{\circ} \mathrm{C}$ and promoted a decrease in respiration rate by 8 times / $\mathrm{min}$.

The proposed technical solution [16, p. 13] allows us to regulate the temperature regime and maintain the relative humidity of air in the cattle-breeding premises. This is achieved by creating a water mist from small droplets with a normalized supply of water to the animal zone, and adjust- 
ing the time between humidification cycles. A distinctive feature of this device is that the nozzles are placed on a horizontal bar with the possibility of changing their height above the floor with brackets. They are equipped with electromagnetic valves with an automatic control unit for their operation. Using this device can be effective in the premises for animals of different age and height.

The device (Figure 5) consists of a circulating water circuit (1), a spray unit (2) with injectors (3), which is equipped with solenoid valves (not shown) and control brackets (4), which are mounted on vertical posts (5) in the corresponding position above the floor surface. The regulation of the water supply and its quantity, as well as the time between humidification cycles, is carried out with the help of the automatic control unit (6).

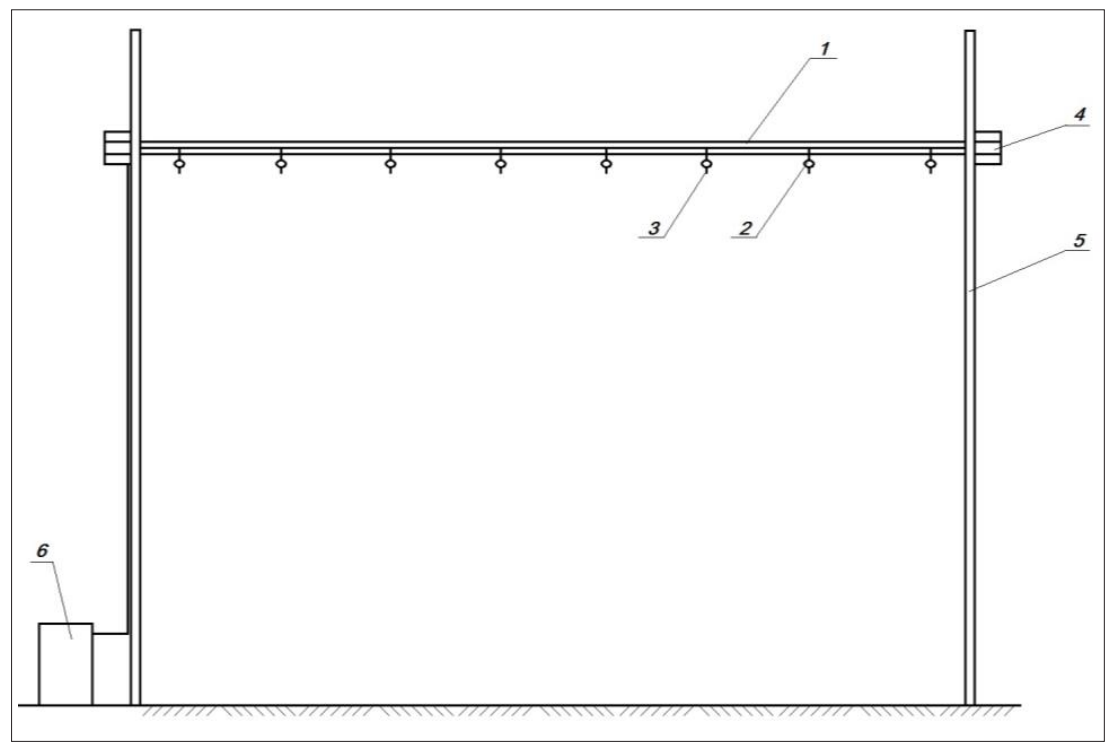

Fig. 5. An apparatus for humidifying and cooling air into the livestock house

The device operates as follows. In hot periods of animal maintenance, when there is a need to reduce the temperature of the air, adjust the height of the brackets (4) above the floor. Water from the main line is fed to the circulation circuit (1), spray units (2). Electro-magnetic valves started or 
stop the flow of water to the injectors (3) using the automatic control unit (6). When high-pressure water exits, a micro drop mist is formed from the nozzles (droplet sizes of up to 30 microns), which eliminates the risk of wetting the litter material. Due to the evaporation of parts of the water, the cattle-breeding premises are roughly cooled to $4 \ldots 10^{\circ} \mathrm{C}$. There is also the possibility of using a set of equipment for disinfection of large-sized premises of an industrial complex [21, p. 60].

Thus, the technical solutions proposed by the staff of the Dnepropetrovsk State Agrarian and Economic University can be effectively used to maintain the health of the dairy herd of cows and prolong their productive longevity in industrial technology.

\section{Conclusions}

1. High temperatures during the summer period contributed to a decrease in milk yield and the main components of milk of the Ukrainian Schwitz. Therefore, to prevent the harmful effects of high temperatures on animals in conditions of year-round maintenance in barns of lightweight construction, it is advisable to use active ventilation systems with air humidification.

2. The THI indicator, which exceeded the comfortable value for dairy cows in the warm period of 2017 (May-September) was recorded for 100 days. As a result of high temperatures in the hot season of 2017, the loss for the dairy herd amounted to 37.5 thousand EUR, or 39.5 EUR per 1 cow.

3. The technical solutions proposed by the staff of the Dnepropetrovsk State Agrarian and Economic University can be effectively used to maintain the health of the dairy herd of cows and prolong their productive longevity in industrial technology.

\section{References:}

1. Baumgard, L. H., \& Rhoads, R. P. (2013). Effects of Heat Stress on Postabsorptive Metabolism and Energetics. Annual Review of Animal Biosciences, 1(1), 311-337. doi:10.1146/annurev-animal-031412-103644.

2. Bernabucci, U., Ronchi, B., Lacetera, N., \& Nardone, A. (2002). Markers of Oxidative Status in Plasma and Erythrocytes of Transition Dairy Cows During Hot Season. Journal of Dairy Science, 85(9), 2173-2179. doi:10.3168/jds. s0022-0302(02)74296-3.

3. Bouraoui, R., Lahmar, M., Majdoub, A., Djemali, M., \& Belyea, R. (2002). The relationship of temperature-humidity index with milk production of dairy cows in a Mediterranean climate. Animal Research, 51 (6), 479-491. doi:10.1051/animres:2002036. 
4. Bravo, D. M., \& Wall, E. H. (2016). The rumen and beyond: Nutritional physiology of the modern dairy cow 1. Journal of Dairy Science, 99(6), 4939-4940. doi:10.3168/jds.2015-10191.

5. Burjakov, N.P., M.A. Burjakova, \& D.E. Aleshyn (2016). Teplovoj stress y osobennosty kormlenyja molochnogo skota Rossyjskyj veterynarnыj zhurnal, 3, 5-13 (in Russian).

6. Caso, J., Leza, J., \& Menchen, L. (2008). The Effects of Physical and Psychological Stress on the Gastrointestinal Tract: Lessons from Animal Models. Current Molecular Medicine, 8 (4), 299-312. doi:10.2174/156652408784533751.

7. Das, R., Sailo, L., Verma, N., Bharti, P., Saikia, J., Imtiwati, \& Kumar, R. (2016). Impact of heat stress on health and performance of dairy animals: A review. Veterinary World, 9 (3), 260-268. doi:10.14202/vetworld.2016.260-268.

8. Do Amaral, B. C., Connor, E. E., Tao, S., Hayen, M. J., Bubolz, J. W., \& Dahl, G. E. (2011). Heat stress abatement during the dry period influences metabolic gene expression and improves immune status in the transition period of dairy cows. Journal of Dairy Science, 94 (1), 86-96. doi:10.3168/jds.2009-3004.

9. Fournel, S., Ouellet, V., \& Charbonneau, É. (2017). Practices for Alleviating Heat Stress of Dairy Cows in Humid Continental Climates: A Literature Review. Animals, 7(12), 37. doi:10.3390/ani7050037.

10. Halliwell, B. (2012). Free radicals and antioxidants: updating a personal view. Nutrition Reviews, 70 (5), 257-265. doi:10.1111/j.1753-4887.2012.00476.x.

11. Kadzere, C.., Murphy, M.., Silanikove, N., \& Maltz, E. (2002). Heat stress in lactating dairy cows: a review. Livestock Production Science, 77 (1), 59-91. doi:10.1016/s0301-6226(01)00330-x.

12. Liu, Z., Ezernieks, V., Wang, J., Arachchillage, N. W., Garner, J. B., Wales, W. J., ... Rochfort, S. (2017). Heat Stress in Dairy Cattle Alters Lipid Composition of Milk. Scientific Reports, 7(1). doi:10.1038/s41598-017-01120-9.

13. López-Gatius, F., \& Hunter, R. (2017). Clinical relevance of pre-ovulatory follicular temperature in heat-stressed lactating dairy cows. Reproduction in Domestic Animals, 52 (3), 366-370. doi:10.1111/rda.12916.

14. Milostivyj R.V., Vasilenko T.O., Vysokos N.P., Kalinichenko A.A., \& Milostivaja D.F. (2017). Ocenka verojatnosti razvitija teplovogo stressa u vysokoproduktivnyh korov v uslovijah centra Ukrainy. Materialy mezhdunarodnoj nauchno-prakticheskoj konferencii "Prodovol'stvennaja bezopasnost': ot zavisimosti k samostojatel'nosti" (12-13 dekabrja). Smolensk, 229-237 (in Russian).

15. Milostivyj, R.V., Visokos, N.P., Priluckaja, E.V. \& Tihonenko, V.A. (2016). Meroprijatija po stabilizacii mikroklimata $\mathrm{v}$ zhivotnovodcheskih pomeshhenijah $\mathrm{v}$ zharkih pogodnyh uslovijah. Prioritetnye i innovacionnye tehnologii v zhivotnovodstve - osnova modernizacii agropromyshlennogo kompleksa Rossii: Sb. nauch. statej. - Stavropol', 291-295 (in Russian).

16. Pugach, A.M., Visokos, M.P., Milostivij, R.V., Tjupina, N.V. \& Kalinichenko, A.O. (2016). Patent na korisnu model' № 108437, MPK F24F 6/12 "Pristrij dlja zvolozhennja ta oholodzhennja povitrja v tvarinnic'komu primishhenni"; Zajavl. 26.02.16. Opubl. 11.07.2016. Bjul. № 13 (in Ukrainian).

17. Pyron, O., \& Y. Malynyn (2015). Nuzhno ly predotvrashhat' teplovoj stress u dojnыh korov? Эffektyvnoe zhyvotnovodstvo, 3-4 (113), 18-20 (in Russian). 


\section{Influence of high temperature on dairy productivity of Ukrainian schwyz...}

18. Rashid, M., Hossain, M., Azad, M., \& Hashem, M. (2013). Long term cyclic heat stress influences physiological responses and blood characteristics in indigenous sheep. Bangladesh Journal of Animal Science, 42(2). doi:10.3329/bjas. v42i2.18486.

19. Spiers, D. E., Spain, J. N., Sampson, J. D., \& Rhoads, R. P. (2004). Use of physiological parameters to predict milk yield and feed intake in heat-stressed dairy cows. Journal of Thermal Biology, 29(7-8), 759-764. doi:10.1016/j.jtherbio.2004.08.051.

20. Vasilenko T., Milostiviy R., Kalinichenko A., Milostiva D. (2018). Heat stress in dairy cows in the central part of Ukraine and its economic consequences. Social and economic aspects of sustainable development of regions. Monograph. Opole, 128-135.

21. Vysokos M.P., Milostiviy R.V., Kalinichenko O.O., Tikhonenko V.A., Sanzhara R.A. (2017). Technical support of aerosol processing for large groups of animals under the conditions of the industrial complex. Science and Technology Bulletin of SRC for Biosafety and Environmental Control of AIC, 5 (1), 60-64.

22. Vysokos, M.P., Milostiviy, R.V., Typina, N.V., \& Kalinichenko, A.O. (2015). Zoogigijenichna ocinka umov utrymannja molochnogo gurtu golshtyns'koi' hudoby za parametramy mikroklimatu monobloku korivnyka v regioni Prydniprov'ja. Naukovo-tehnichnyj bjuleten' NDC biobezpeky ta ekologichnogo kontrolju resursiv APK, 3(4), 74-78 (in Ukrainian).

23. Wolfenson, D., Flamenbaum, I., \& Berman, A. (1988). Dry Period Heat Stress Relief Effects on Prepartum Progesterone, Calf Birth Weight, and Milk Production. Journal of Dairy Science, 71(3), 809-818. doi:10.3168/jds.s0022-0302(88)79621-6. 